\title{
CARTILAGE INTEGRATION: EVALUATION OF THE REASONS FOR FAILURE OF INTEGRATION DURING CARTILAGE REPAIR. A REVIEW
}

\author{
I.M. Khan, S.J. Gilbert, S.K. Singhrao, V.C. Duance, C.W. Archer* \\ Connective Tissue Biology Laboratories, School of Biosciences, Cardiff University, Museum Avenue, \\ Cardiff, CF10 3US, Wales, UK .
}

\begin{abstract}
Articular cartilage is a challenging tissue to reconstruct or replace principally because of its avascular nature; large chondral lesions in the tissue do not spontaneously heal. Where lesions do penetrate the bony subchondral plate, formation of hematomas and the migration of mesenchymal stem cells provide an inferior and transient fibrocartilagenous replacement for hyaline cartilage. To circumvent the poor intrinsic reparative response of articular cartilage several surgical techniques based on tissue transplantation have emerged. One characteristic shared by intrinsic reparative processes and the new surgical therapies is an apparent lack of lateral integration of repair or graft tissue with the host cartilage that can lead to poor prognosis. Many factors have been cited as impeding cartilage:cartilage integration including; chondrocyte cell death, chondrocyte dedifferentiation, the nature of the collagenous and proteoglycan networks that constitute the extracellular matrix, the type of biomaterial scaffold employed in repair and the origin of the cells used to repopulate the defect or lesion. This review addresses the principal intrinsic and extrinsic factors that impede integration and describe how manipulation of these factors using a host of strategies can positively influence cartilage integration.
\end{abstract}

Keywords: cartilage, integration, repair, autologous chondrocyte implantation.

\footnotetext{
*Author for correspondence:

Professor Charles W Archer

Connective Tissue Biology Labs

School of Biosciences

Cardiff University

Museum Avenue

Cardiff CF10 3US

Wales, UK.
}

Telephone: +44 (0)2920 875206

Fax: +44 (0)2920 874594

E-mail: archer@cardiff.ac.uk

\section{Introduction}

Articular cartilage is a highly organised avascular and aneural tissue that provides a smooth surface for the movement of articulating bones and transmission of loads (Muir, 1995). Cartilage carries out the latter function by transferring the forces generated by locomotion to the underlying bone. The resident cells of articular cartilage are chondrocytes that are surrounded by an extensive extracellular matrix whose primary constituents are water, aggrecans and type II collagen. Aggrecans are rich in covalently bonded glycosaminoglycans that are hydrophilic and whose electronegative properties resist applied compressive forces. The tensile strength required to constrain the electronegative force generated by the aggrecans is provided by an organised network of crosslinked fibrils principally containing type II collagen. In cross-section articular cartilage displays a pseudostratified appearance composed of three unmineralised layers; the superficial zone with small, dicoidal chondrocytes aligned parallel to the surface, a transitional zone where chondrocytes are rounded with no apparent organisation and the radial/deep zone where large chondrocytes are aligned in columns of 4-6 cells at right-angles to the surface, Figure 1. The fourth layer is the calcified zone where mineralisation is restricted to the interterritorial matrix of chondrocytes. The calcified zone borders and interdigitates with the subchondral bone.

\section{Cartilage defects}

\section{Trauma}

In younger patients who have generally suffered trauma to a joint, focal lesions may appear that if untreated may lead to further progressive degeneration over time. Clinically, focal lesions are graded from the appearance of superficial fissures on the surface of articular cartilage, progressing to chondral lesions that eventually degenerate to form osteochondral lesions that penetrate through to the subchondral bony plate (Kleemann et al., 2005). Focal lesions are generally small $\left(<1 \mathrm{~cm}^{2}\right)$ and sub-chondral in form, and therefore asymptomatic (Hjelle et al., 2002), and whilst it is difficult to predict the likelihood that chondral lesions will progress to more extensive degeneration, in animal studies have demonstrated that small defects have the potential to heal while larger defects show an inverse relationship to repair (Jackson et al., 2001). 

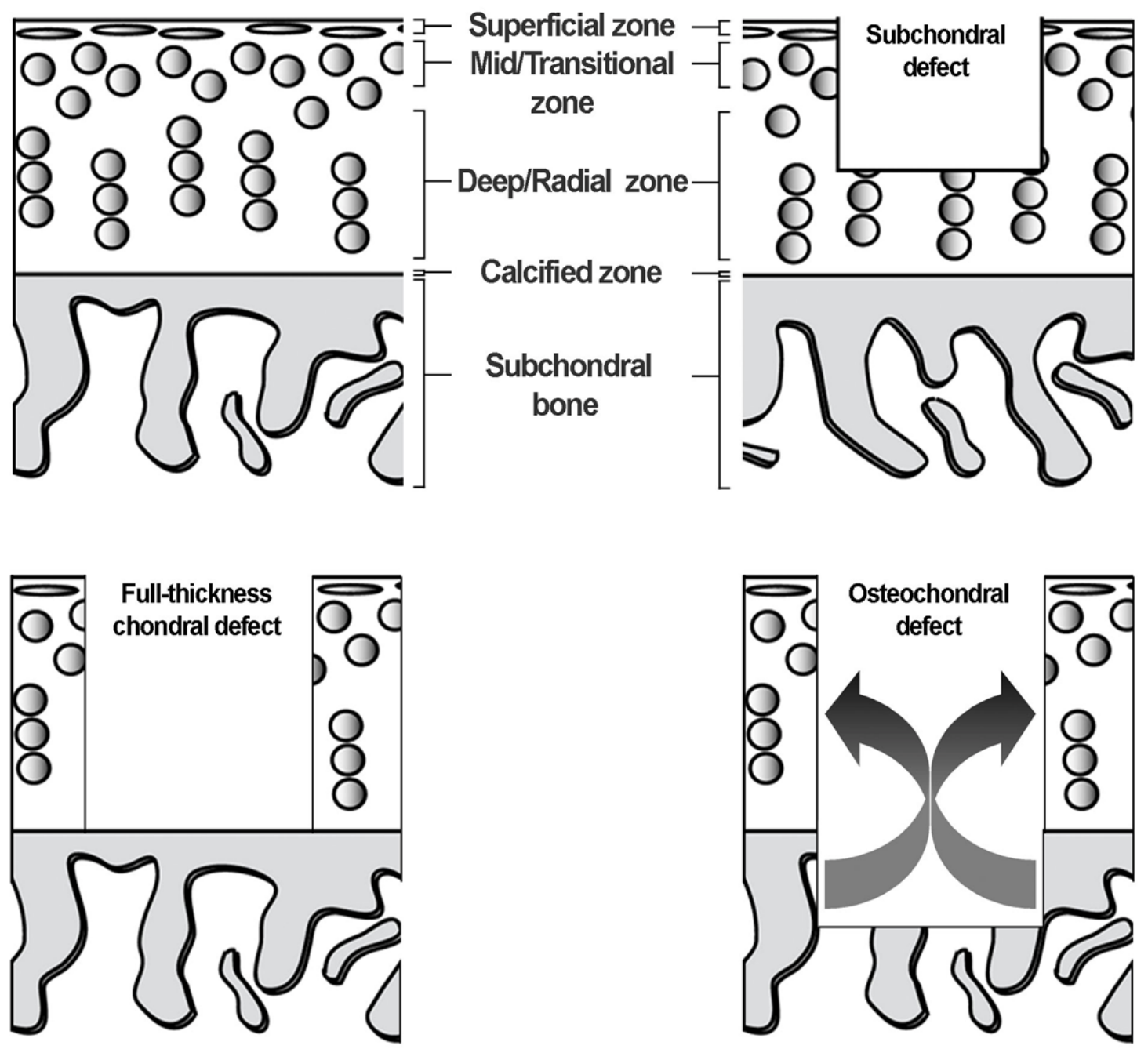

Figure 1. The zonal architecture of mature articular cartilage is depicted. Also shown are examples of lesions, starting with a subchondral lesion, i.e. limited to the articular cartilage, full-thickness chondral lesion that extends to the subchondral bony plate that is itself intact and finally an osteochondral lesion where the integrity of the bony plate is breached. In full-thickness and osteochondral defects spontaneous healing can occur to a greater degree due to the ingress of mesenchymal stem/progenitor cells within the bone into the defect.

\section{Osteoarthritis}

Osteoarthritis is a progressive, heterogeneous, degenerative joint disease, and the most common form of arthritis especially in older people. It is associated with a breakdown of cartilage in joints and can occur in almost any joint in the body (Kuettner and Cole, 2005). It commonly occurs in the weight bearing joints of the hips, knees and spine, but also affects fingers, neck and large toe, but rarely affects other joints unless prior injury or excessive stress is involved. Osteoarthritis causes the cartilage in a joint to become soft and lose its elasticity, making it more susceptible to damage. Over time, the cartilage may erode in some areas, greatly decreasing its biomechanical ability to distribute load and allow smooth articulation. As articular cartilage deteriorates, tendons and ligaments stretch, causing pain. If the condition worsens and little or no cartilage remains, the bones may rub against each other causing great pain. At this stage joint replacement is often the only therapeutic option.

\section{Intrinsic healing of articular cartilage}

Articular cartilage has a very limited capacity to regenerate or repair and this is due in part to its avascular nature, therefore, progenitor cells in blood or marrow, or resident chondrocytes, are unable to migrate to sites of sub-chondral lesions. There is in effect little repair of chondral and subchondral lesions if the lesions are above a critical size. Spontaneous healing of small sub-chondral defects made using a diamond knife have been observed in foetal lambs (Namba et al., 1998) and small $<3 \mathrm{~mm}$ diameter fullthickness defects have been shown to partially heal in rabbits (Shapiro et al., 1993). However, larger osteochondral lesions of more than $6 \mathrm{~mm}$ in diameter rarely if ever heal as demonstrated in a goat defect model and in time lead to progressive degeneration at the lesion site (Jackson et al., 2001). In osteochondral or full-thickness defects the subchondral bony plate is breached, and this leads to the ingress of blood to form a hematoma composed 


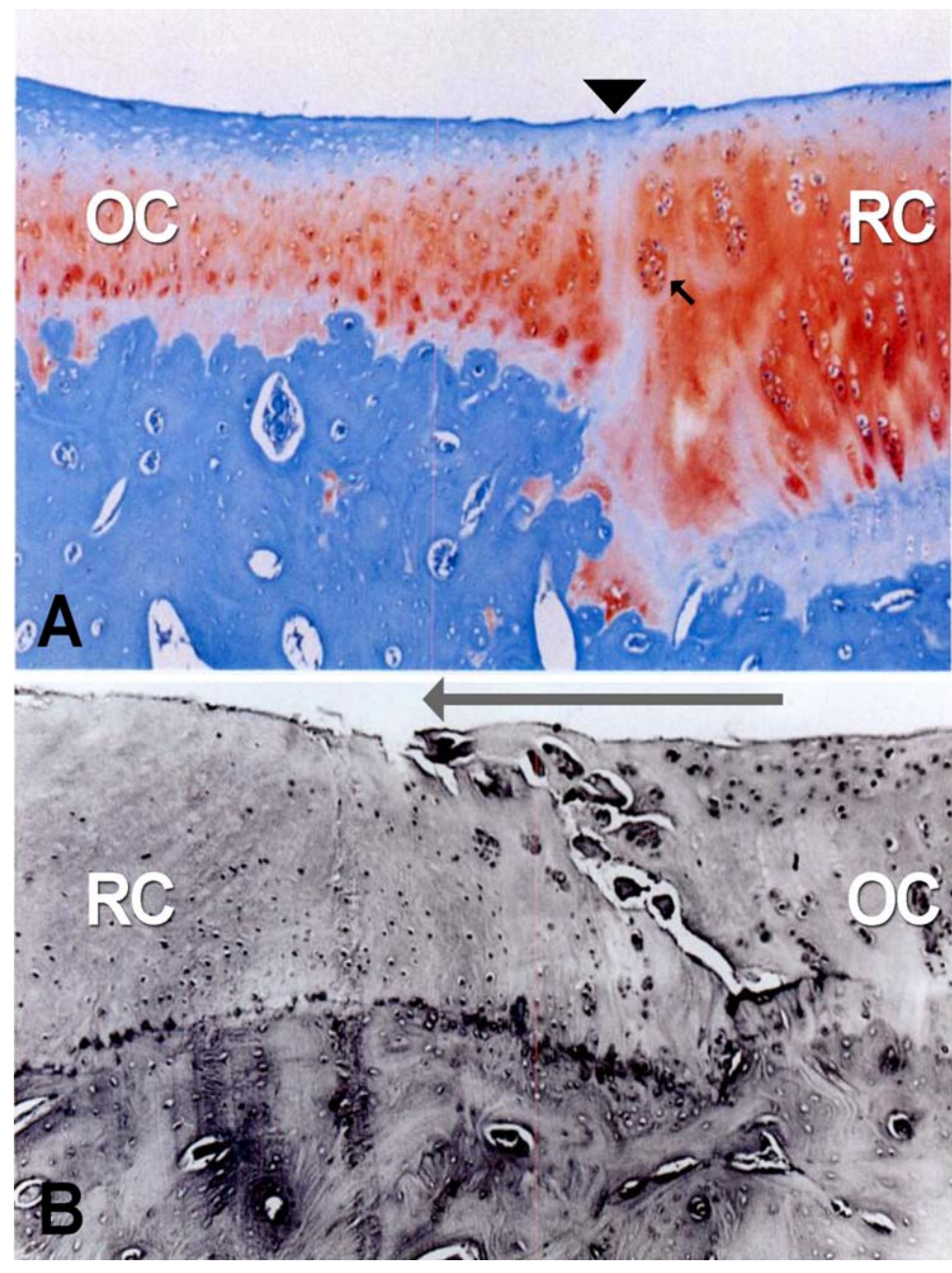

Figure 2. Photomicrographs of osteochondral defects in a rabbit model of cartilage repair after 24 and 48 weeks. (A) The repair cartilage (RC), on the right, shows good surface continuity and the tidemark has been reconstituted after 24 weeks. The junction between repair and original cartilage (OC) is hypocellular (arrowhead) and there is also evidence of chondrocyte cluster formation characteristic of degenerating cartilage (arrowed). (B) After 48 weeks there is significantly reduced lateral integration superficial fibrillations are present as well as deep vertical fissures that reach the tidemark, the cartilage appears more hypocellular and clefting (arrowed) of the remaining tissue into the defect site is occurring. (Shapiro et al., 1993; used with permission. No indication of image magnification or scale bars were given for this figure in the original publication). of a fibrin clot within which are found platelets, red and white blood cells. The blood clot can fill small defects $<2$ $3 \mathrm{~mm}$ in diameter, however, in larger defects the void is not filled. Mesenchymal stem cells, either circulating in the vasculature or derived from the bone marrow, penetrate the fibrin clot and can initiate osseous and chondral repair. The nature of the chondral repair tissue is fibrocartilagenous, whose extracellular matrix is generally composed of a higher ratio of collagen type I to collagen type II and less proteoglycan, that is inferior in its biomechanical function and bears little morphological or structural identity to hyaline cartilage. Though initially, repair and host tissue may be fused, inherent biomechanical weakness of the fibrocartilagenous tissue lead to discontinuities evidenced as microfractures in the lateral margins between host and repair cartilages that evolve into full thickness fissures and lead to the loss of the repair tissue, Figure 2 (Shapiro et al., 1993).

\section{Methods of cartilage repair}

The primary goal of articular cartilage repair is restoration of a functioning joint. In the ideal scenario the repair process and restored tissue are biological in origin, but complete cartilage degeneration necessitates total joint replacement through artificial implants. In most cases clinical intervention has the greatest benefit for symptomatic lesions which are small enough to be filled with cells and repair tissue from various sources (Redman et al., 2005). At the very least the repair tissue should replicate the biomechanical function of the surrounding normal cartilage, allow pain-free articulation, integrate with surrounding host tissue, and prevent further cartilage degeneration.

Intrinsic repair can be stimulated by drilling or microfracturing the subchondral bone plate, an action that exposes the vascular system and bone marrow to the defect void (Steadman et al., 2001). Fibrin clot formation, vascular invasion and recruitment of mesenchymal stem cells into the defect result in chondrogenesis at the wound site. However the resulting cartilage is rarely if ever hyaline in nature: the typical anisotropic characteristics are absent in the repair cartilage. Fibrocartilage or scar tissue that results is inferior biomechanically to normal cartilage and is therefore susceptible to degeneration (Knutsen et al., 2004). Long term animal studies examining the natural repair process following the generation of full-depth defects in articular cartilage in rabbits found that the newly synthesised repair matrix was fibrocartilage in nature, and although it looked stably integrated with surrounding normal tissue at 12 weeks, by 48 weeks the junction had fractured and in almost every case the cartilage was degenerating (Figure 2) (Shapiro et al., 1993).

In osteochondral transplantation (or mosaicplasty), osteochondral plugs are transferred from an undiseased 

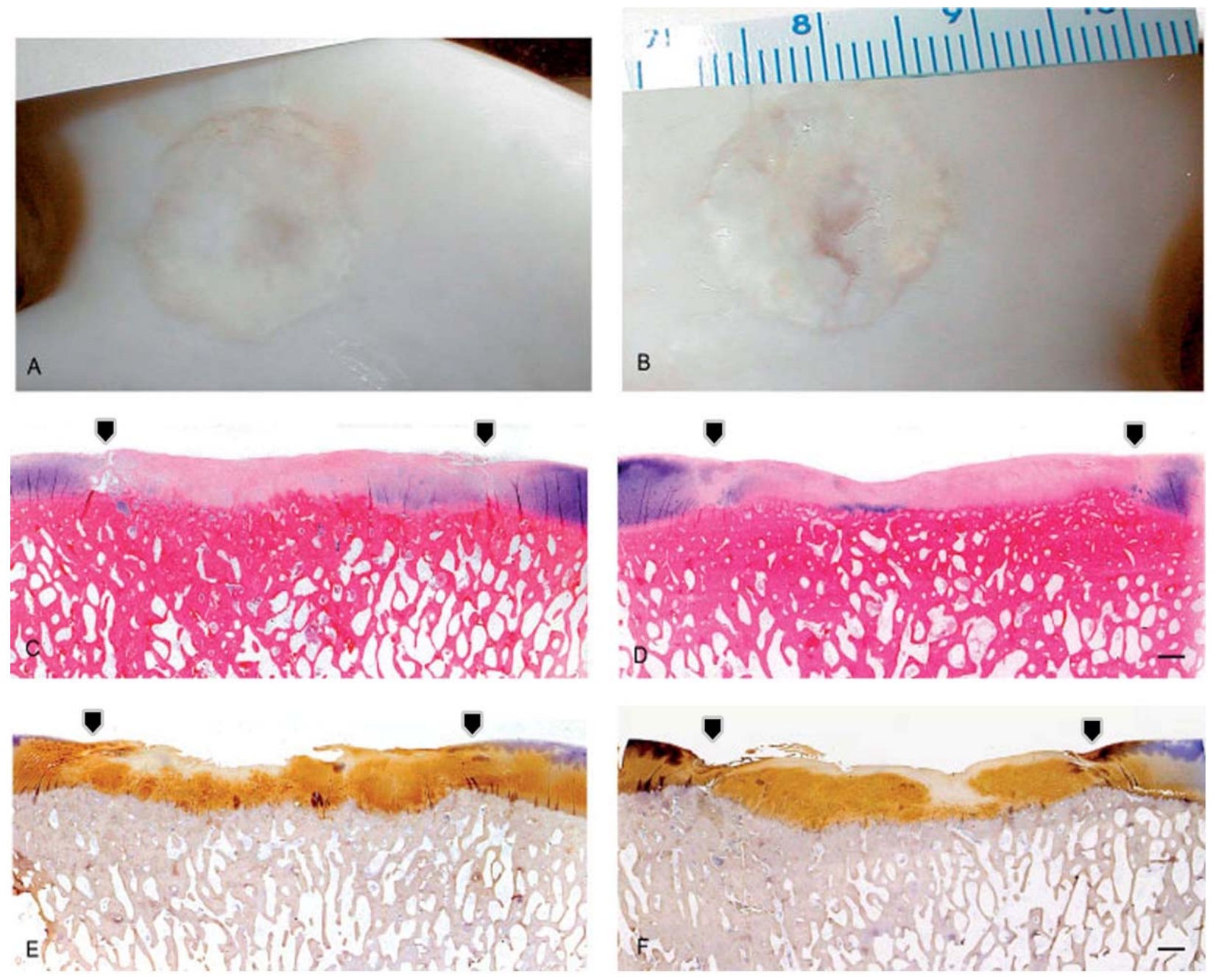

Figure 3. Cartilage repair using implanted mesenchymal stem cells (MSC) in an equine animal model. $15 \mathrm{~mm}$ diameter defects were created and then filled with MSCs entrapped within fibrin or the fibrin vehicle alone. The MSC-fibrin (A) and fibrin (B) implants were evaluated after 8 months, and both showed variable healing of the defect. The presence of microfractures and clefting is apparent in haemotoxylin and eosin stained sections of MSC implanted fibrin (C) and fibrin (D) implants. Collagen type II antibody labelling was present throughout MSCfibrin (E) and fibrin (F) implants. Characteristic signs of failure of cartilage integration are visible such as clefting, delamination, fracturing and fissuring at the boundary (arrowed) between host and repair tissue (Wilke et al., 2007). Scale bar $=1 \mathrm{~mm}$.

and relatively non-weight bearing region to a debrided lesion site (Matsusue et al., 1993). The advantages of the technique are that rapid bone healing provides good vertical fixation of osteochondral plugs into the implant site and that relatively larger defects can be filled using this technique. However, studies have shown that this technique results in donor site morbidity and extensive cell death of chondrocytes in the superficial aspect and margins of the osteochondral plugs (Huntley et al., 2005). There is little evidence of integration of osteochondral plugs with surrounding cartilage (Horas et al., 2003) and this probably accounts for biomechanical failure at the interface regions leading to further cartilage degeneration .

Periosteal or perichondreal grafts have been used extensively to heal cartilage defects (Amiel et al., 1985; O'Driscoll and Salter, 1986). It was discovered that the cambial layer of grafts contain adult progenitor cells that can differentiate into chondrocytes, but, despite that fact in some cases hyaline cartilage repair tissue is formed there is little evidence of lateral integrative repair (Zarnett et al., 1987). One option to treat focal lesions is autologous chondrocyte implantation (ACI) (Grande et al., 1989). A small cartilage tissue biopsy is taken arthroscopically, chondrocytes are then enzymatically isolated and culture expanded in vitro under conditions that maintain chondrogenic potential of the cells. Subsequently, the expanded cells are harvested and transplanted with fibrin beneath a periosteal flap sutured around the defect. Treatment with ACI results in repair tissue of varying morphology, in one study $78 \%$ of all biopsies from grafted regions of ACI patients showed fibrocartilagenous repair (Roberts et al., 2003). In a study to compare ACI with microfracture, at 2 and 5 years post-operative, both groups showed significant clinical improvement but no significant difference in clinical outcome (Coleman et al., 2001). Short-term animal studies show that chondrocytes persist in the defect and display some integration with host tissue (Dell'Accio et al., 2003). The periosteal flap can be 


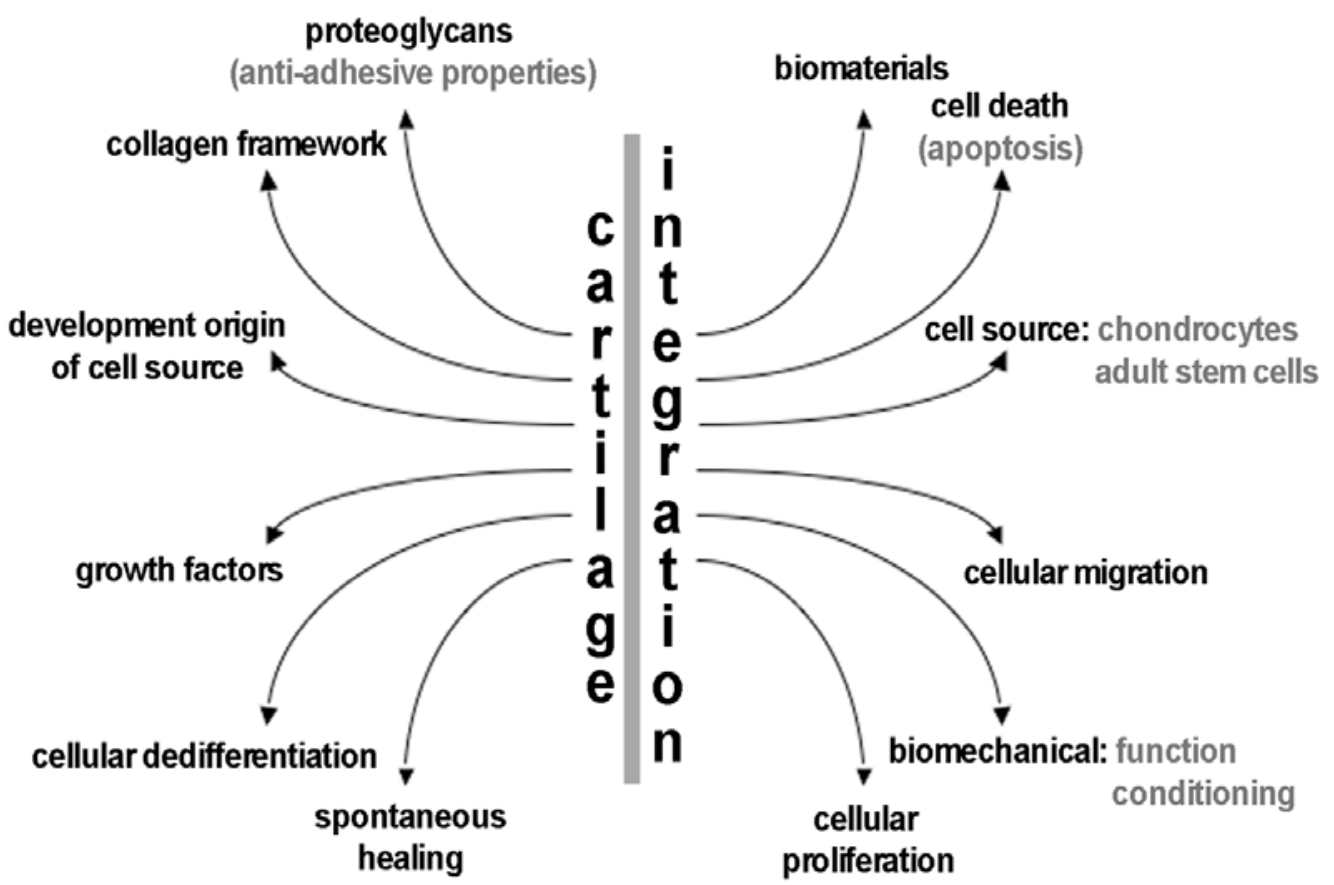

Figure 4. Factors known to directly or indirectly affect lateral integrative cartilage repair.

replaced with a synthetic biomaterials, such as a collagenous scaffold consisting of collagen type I and III, and used in matrix-assisted chondrocyte implantation (MACI) procedures, potentially reducing the risks of hypertrophy and ossification associated with periosteal tissue and increasing the stability of the graft (Russlies et al., 2002). Whilst a prospective randomized trial of MACI versus ACI $(n=99)$ showed no difference between either procedure in clinical outcomes (Bentley et al., 2003), another prospective study ( $n=63$ ) using MACI for repair of chondral defects described no example of symptomatic graft hypertrophy (Behrens et al., 2006). An example of the type of cartilage integration typically observed in animal studies is shown in Figure 3. Clefting of the surrounding cartilage over the grafted tissue is common, as are microfractures and larger fissures at the interface between 'normal' and repair tissue.

\section{Factors impeding integrative cartilage repair}

There are numerous factors that directly and indirectly affect tissue integration, summarised in Figure 4, and although the weight of each factor on impeding cartilage fusion may vary, better understanding of their effects may lead to improved strategies to enhance lateral integration following cartilage repair.

\section{Chondrocyte cell death}

It is implicitly understood that chondrocyte viability at the graft and host edges is an important determinant of the quality of repair. Cell death can occur during preparation of the defect site prior to accepting a graft, or within the grafted cells. Using a porcine model of ACI, Hunziker \& Quinn reported significant cell death at the interface between host and repair tissue in partial thickness chondral defects (Hunziker and Quinn, 2003). In vitro wounding of articular cartilage induces a zone of cell death characterized initially by a band of necrosis 100-200 microns from the initial mechanical trauma followed by progressive apoptosis over a 14 day period that penetrates the tissue up to 400 microns laterally (Redman et al., 2004; Tew et al., 2000). This zone of cell death likely hinders integration between neo-cartilage and existing tissue, as maintenance of normal articular cartilage is dependent on maintaining cell density and cell phenotype. Perturbation of these latter factors results in sub-optimal matrix production forming biomechanically compromised tissue that may lead to mechanical failure (Archer et al., 2006). Surviving cells behind the necrotic zone of cell death re-enter the cell cycle and divide, but they occupy the same lacunae as daughter cells, and therefore are unable to repopulate the matrix leaving a characteristic acellular zone (Tew et al., 2000). Interestingly, in vitro three-dimensional pellet culture of combinations of $1 \mathrm{~mm}^{3}$ intact pieces of sternal cartilage and freshly isolated sternal chondrocytes from embryonic chicks results in necrosis and apoptosis at the interface between growing neo-cartilage and native intact cartilage (Zhang et al., 2005), consistent with observations for experimental wounding of the same tissue (Walker et al., 2000). Furthermore, integration between cell-seeded matrices and articular cartilage is inhibited relative to unseeded matrices or devitalized articular cartilage (Giurea et al., 2002; Peretti et al., 2006). We have noted similar occurrences with combinations of live and dead neocartilages grown in opposition, arguing that this inhibitory phenomenon is not limited to native cartilages (Redman et al., 2005). The nature of the refractory signal between opposed cartilages is open to question, but requires living chondrocytes to propagate it. Repopulation of devitalized cartilage can enhance cartilage:cartilage integration as demonstrated by Peretti et al. (1998) who 

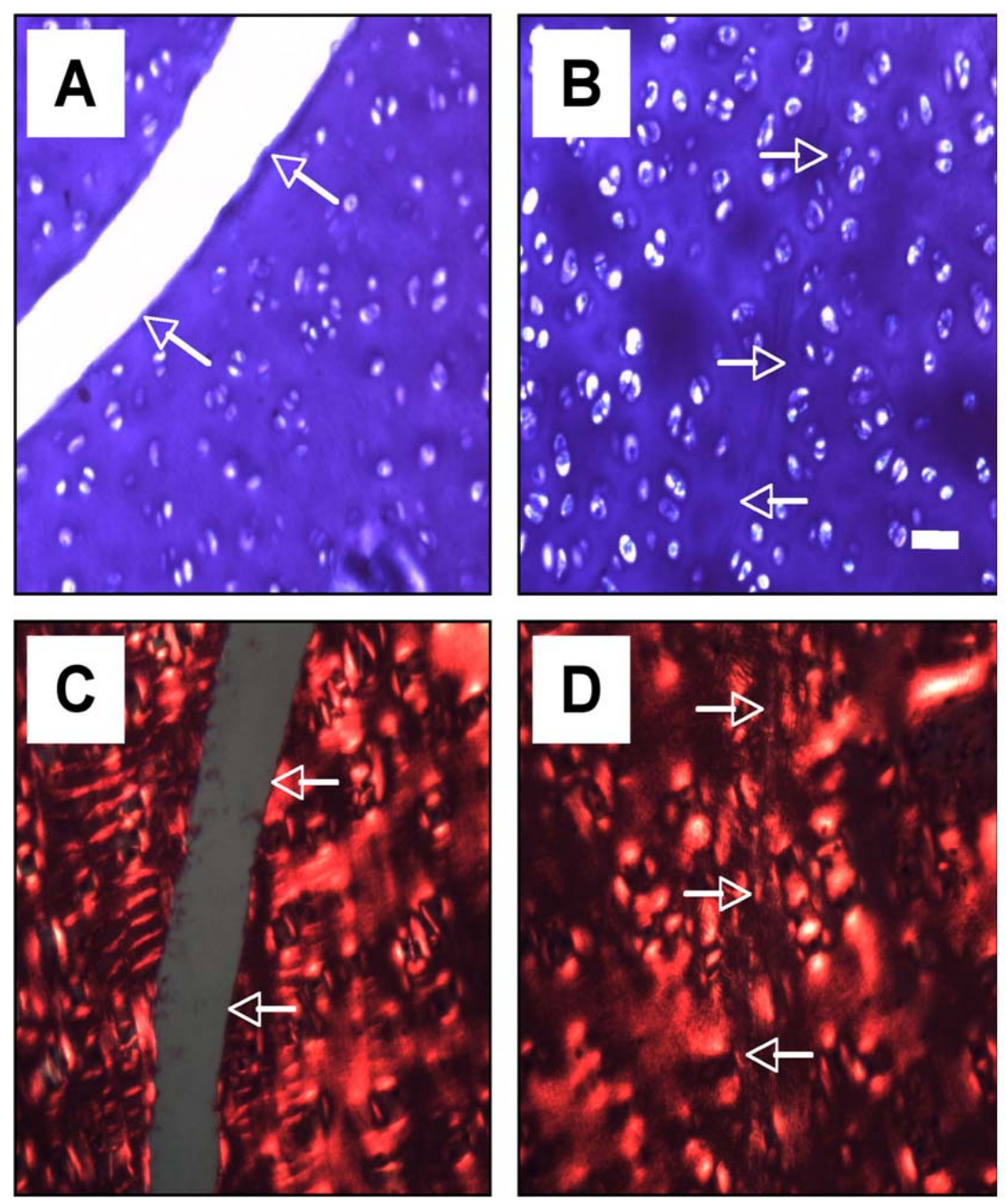

Figure 5. Inhibition of chondrocyte death enhances cartilage integrative repair. Disk/ring bovine cartilage composites were cultured in the absence (A \& C) or presence (B \& D) of the pan-caspase inhibitor, ZVAD-FMK $(20 \mu \mathrm{M})$. At the end of 2weeks in culture, cartilage was fixed, embedded in wax and $8 \mu \mathrm{m}$ sections assessed for integration by staining with toluidine blue or picrosirius red. Sections were viewed by standard light (A \& B) or polarising light microscopy (C \& D). Arrows indicate the wound edge. Scale bar $=100 \mu \mathrm{m}$.

precultured devitalized ovine cartilage slices with isolated chondrocytes then recombined slices with fibrin glue and implanted them into nude mice for up to 42 days (Peretti et al., 1998). Bonding of cartilage slices occurred in all samples that were precultured with chondrocytes prior to implantation but never in the absence of cells.

Apoptotic cell death of chondrocytes can be inhibited in cartilage using caspase inhibitors such as ZVAD-fmk (D'Lima et al., 2001), and has been applied to an animal model of full-thickness defect repair where intra-articular injections caused partial rescue of cell death but only well behind the wound margin, i.e. an acellular zone was still present (Costouros and Kim, 2007). Our own investigations have demonstrated that the presence of ZVAD-fmk in the culture medium enhances cartilagecartilage integration (Figure 5).

\section{Chondrocyte phenotype}

Autologous chondrocyte implantation requires between 530 million chondrocytes depending on the size of defect to be filled and the procedure used (Bentley et al., 2003). On average $4.5 \times 10^{5}$ cells are harvested from a typical $100 \mathrm{mg}$ biopsy from patients aged 40 and above, thus in vitro monolayer expansion is required to generate sufficient cells, between 10-20 ×106, for implantation (Barbero et al., 2004). During the expansion phase chondrocytes undergo dedifferentiation adopting a fibroblastic morphology and phenotype (Benya and Shaffer, 1982). Dedifferentiated human chondrocytes can redifferentiate in three-dimensional high-density culture following 1-5 passages but more extensive expansion limits this capacity (Benya and Shaffer, 1982; Schulze-Tanzil et al., 2002). Benya \& Shaffer observed that a small fraction of low passage dedifferentiated chondrocytes do not differentiate (Benya and Shaffer, 1982), thus incomplete redifferentiation of expanded chondrocytes can indirectly affect integration through compromising normal chondrocyte phenotype and function (Yan and Yu, 2007).

\section{Donor age related effects}

There are an abundance of studies that have described agerelated decline in chondrocyte function, such as reductions in proliferative potential, sulphated glycosaminoglycan production, collagen deposition and responsiveness to growth factors (Barbero et al., 2004; Blaney Davidson et al., 2005; Martin et al., 2002; Singh et al., 2007; Tew et al., 2001). It is estimated that in vitro expansion ages chondrocytes approximately 30 years based on measurements of telomere length, implying replicative senescence of chondrocytes can potentially impede integration through accelerated aging (Barbero et al., 2004; Martin et al., 2002; Parsch et al., 2002). The appearance 
of even a small cohort of senescent cells within an expanded population has the potential to disrupt normal function, as senescent cells have reduced synthetic capacity and can adopt a pro-inflammatory, catabolic phenotype, through constitutive expression of metalloproteinases (Linskens et al., 1995; Martin and Buckwalter, 2002). In order to circumvent some of these difficulties the use of mesenchymal stem cells (MSC) has been advocated as plentiful, reproducible and chondrogenic cell source for articular cartilage tissue repair, although inefficient chondrogenesis or inappropriate differentiation into the endochondral pathway can be problematic (Caplan and Bruder, 2001; Dowthwaite et al., 2003; Kafienah et al., 2007; Tatebe et al., 2005). The question arises; if repair is age-dependent then will heterochronic pairing of young and old tissues improve integration? Transplantation of complete 11-day-old epiphyses from chick embryos into defects created in the weight-bearing area of the tibiotarsal joint of mature animals resulted in production of hyaline cartilage in vivo (Cohen et al., 2006), there was restoration of surface continuity and lateral integration was complete after 4 weeks. Similar results were obtained in vitro using epiphyseal chondrocytes embedded in a collagen-fibrin gel (Perka et al., 2000). Embryonic epiphyses when maintained in vitro in 'joint-stimulating culture' do display metabolic features more characteristic of articular chondrocytes, and in support of this, work by GarciadiegoCazares et al. has shown that under the appropriate conditions embryonic chick epiphyseal chondrocytes can initiate the formation of ectopic synovial joints in vitro (Cohen et al., 2005; Garciadiego-Cazares et al., 2004). Mammalian studies have shown that following the conjunction of combinations of foetal, neonatal and adult tissues, the strength of integration is a function of differences in biosynthetic capacities and in the type of matrix produced (DiMicco et al., 2002; Giurea et al., 2002). Donor age-dependent affects were also observed when costal chondrocytes (from either 4 or 24 week old donors) were transplanted in full-thickness osteochondral defects in rabbits, where it was demonstrated that as well as better repair another advantage of using immature tissue was higher cell yield (Szeparowicz et al., 2006). Therefore, the use of more immature cells or tissues for cellular repair has obvious benefits, and whilst the scope of intervention is thus far limited to adult stem cells, the use of reprogrammed embryonic stem cells offers the hope of further advances (Darabi and Perlingeiro, 2008).

\section{Developmental origins}

To counter the limitations of in vitro culture expansion of dedifferentiated chondrocytes and their reduced potential for redifferentiation into articular chondrocytes following culture expansion, alternative chondrogenic sources for tissue engineering have been sought. In a comparative study of bovine articular, nasoseptal, auricular and costal cartilages, Isogai et al. found significant differences in the biosynthetic and proliferative capacities of each type of chondrocyte (Isogai et al., 2006). Neocartilage formation in cell-seeded scaffold implanted in athymic mice showed that scaffolds containing costal chondrocytes were larger followed by nasoseptal, auricular then articular chondrocytes. Despite these metabolic differences, costal, auricular and articular chondrocytes suspended in fibrin glue all appear to integrate with surrounding discs of articular cartilage (Johnson et al., 2004). However if the extracellular matrices from the various cartilages are left intact no fusion occurs, implying extrinsic factors determine the extent of integration. Articular cartilage is mesodermally-derived and nasal cartilage neural crestderived, does this fact impinge on their ability to fuse or integrate? Experiments have been conducted to address whether two cartilages from different developmental origins but from the same organism are capable of fusing. In one study it was found that mixing of embryonic chick somatic mesoderm with somatopleurally derived mesenchyme resulted in segregation of populations (Zwilling, 1968). In another experiment it was found that stage 22 chick limb mesenchyme and 12-day mouse mesenchyme did not segregate into separate populations hence the differentiation status and origin of tissue might override species barriers to integration. Recognition of these fundamental intrinsic barriers to integration or fusion is of paramount importance.

\section{Collagen network}

Collagen forms the structural framework underpinning the functional capabilities of the tissue, and therefore integration of collagen fibrils is probably a major factor in influencing the success or failure of integrative cartilage:cartilage repair. Dimicco \& Sah showed that integration between live and devitalised cartilages was dependent on collagen deposition (DiMicco and Sah, 2001), and that any differences in fusion between cartilages at different developmental stages could be accounted for by differences in lysyl-oxidase mediated collagen crosslinking (DiMicco et al., 2002). Modulation of lysyloxidase mediated collagen crosslinking of cartilage prior to fusion using an inhibitor, $\beta$-aminopropionitrile, accelerates collagen maturation through a build-up of collagen crosslink precursors and increases the adhesive strength of joined cartilages as precursors are rapidly crosslinked (McGowan and Sah, 2005). An alternative approach to enhance integration has been to enzymatically digest cartilage interfaces prior to attempted fusion (Silverman et al., 2000). Disruption of the collagen network in cartilage either through injury or through collagenase digestion results in cellular proliferation (Lee et al., 1993; Tew et al., 2000). Collagenase treatment of immature bovine articular cartilage prior to fusion enhances integration over the whole interface and increases mechanical strength in push-out tests (Bos et al., 2002; van de Breevaart Bravenboer et al., 2004). Increases in integration were attributed to repopulation of previously acellular tracts at the lateral margins of the host and graft cartilages that promote subsequent deposition of collagen. Breakdown of the collagenous matrix also has a profound effect on the control of proteoglycan synthesis, resulting in greater synthesis for longer duration following collagenase digestion compared with hyaluronidase digestion (Lee et al., 1994). Enzymatic pre-treatment of 
articular cartilage also promotes chondrocyte outgrowths at a rate ten times to that of untreated cartilage (Qiu et al., 2000). The integrative properties of collagenase digest have been extended to show that partially digested slices of articular cartilage can be quickly reconstituted within biphasic scaffolds (Liao et al., 2007). Collagenase digest accelerates implanted cartilage slice integration, accelerating the formation of a biomechanically stable tissue, but also facilitating chondrocyte outgrowth causing chondrocytes to migrate and colonise the remaining scaffold, enhancing both vertical and lateral integration. Steroid hormones such as dihydroepiandrosterone and $17 \beta$ estradiol have also been shown to strongly support in vitro cartilage:cartilage integration in a dose-dependent manner, that is thought to be related to an anabolic response related to collagen turnover (Englert et al., 2006). In support of the latter finding, the fact that in post-menopausal women replacement hormone therapy causes a significant decrease in urine C-telopeptides of type II collagen is thought to be relevant (Ravn et al., 2004). These data collectively suggest that collagen degradation, synthesis, deposition and processing are important in integrative cartilage repair.

\section{Proteoglycans}

The presence of proteoglycans provides an instrinsic barrier for chondrocyte migration to the site of wounding. Enzymatic removal of glycosaminogycan chains of proteoglycans or proteoglycans themselves using chondroitinase $\mathrm{ABC}$, trypsin or hyaluronidase (in combination with collagenase) have been used as strategies to enhance repair through increased chondrocyte mobility (Hunziker and Kapfinger, 1998; Lee et al., 2000; Obradovic et al., 2001). The combination of proteoglycans loss using guanidine or trypsin digestion, and compression during bonding using chemical crosslinkers such as glutalaldehyde and 1-ethyl-3-diaminopropyl-carbodiimide (EDC)/N-hydroxysuccinimide has also been shown to enhance adhesion of cartilage surfaces (Englert et al., 2007). One promising avenue for fusing cartilages involves using biological glue made by chemically modifying chondroitin sulphate biopolymers with methacrylate and aldehyde groups to bridge biomaterials and tissue proteins. This technique has been used to stably integrate hydrogels in lapine models of full-thickness critically sized defects $(6 \mathrm{~mm})$ where cartilage repair with full integration was observed following marrow stimulation (Wang et al., 2007). An earlier tissue-bonding technique used tissue transglutaminase to also bind opposing cartilage surfaces together and promote integration (Jurgensen et al., 1997).

Molecules locally present in the synovial fluid of diathroidal joints which provide important lubrication of the articular surface are also believed to play a significant role in inhibiting cartilage integration (Schaefer et al., 2004). One key molecule is thought to be PRG4 (SZP/ lubricin/megakaryocyte stimulating factor precursor), a glycoprotein synthesised by cells within the synovial tissue as well as within the superficial zone of articular cartilage. Its role is to provide boundary lubrication of congruent articular surfaces under conditions of high contact pressure. Using a disc/ring composite model of cartilage integration, it was found that after 6 -weeks of culture, the adhesive strength of control composites was 10-fold higher than that of composites continuously cultured in the presence of PRG4 (Schaefer et al., 2004). In addition, PRG4 treated composites exhibited interrupted contact zones. It was concluded that PRG4 reduces the integrative capacity of articular cartilage. Englert et al. (2005) have also hypothesised that the articular surface and components of synovial fluid particularly PRG4 and hyaluronic acid have an inhibitory role in cartilage integration (Englert et al., 2005).

\section{Biomaterials and cartilage integration}

The second generation of articular cartilage therapies have involved the extensive application of scaffold technologies to enhance repair and regeneration (Frenkel and Di Cesare, 2004; Martin et al., 2007). Scaffolds are likely to be advantageous in that they: deliver the repair materials to the site of injury; remain in place long enough to effect repair; provide an even distribution of implanted cells; provide an instructive three dimensional environment for seeded and colonising cells; allow for the controlled local delivery of polypeptide or chemical molecules that stimulate repair (Kuo et al., 2006). Additionally, scaffolds can impart some initial biomechanical integrity to the nascent repair tissue such that cell viability is maintained through prevention of injurious compressive and shear stresses, and through prevention of creeping or collapse of the host cartilage into the defect site.

In osteochondral defects scaffold integration, driven by implanted or host cells, occurs most readily in the vertical plane where subchondral bone remodelling and re-establishment of the tidemark are frequently observed following long-term evaluations of repair (Emans et al., 2005). In the first instance it is preferable to have vertical integration as this prevents delamination of the graft, however establishing lateral integration of the scaffoldassisted repair tissue is a chronic problem. Tognana et al. (2005) have established that cell-seeded engineered constructs integrate better with bone or devitalized bone displaying higher glycosaminoglycans content, construct adhesion and sheer modulus than for constructs paired with articular cartilage where negative correlations were obtained for the same parameters (Tognana et al., 2005). Understandably, the primary consideration for effective repair has been filling the defect void and generation of fibrocartilagenous or hyaline repair tissue, and this is highlighted in the weight these factors are given in scoring schemes for assessing repair in experimental studies, where successful lateral integration is generally accounts for $<10 \%$ of the overall score (Wakitani et al., 1994). Therefore, it is possible to demonstrate a significant improvement in scaffold-assisted cartilage repair in the absence of lateral integration. In the clinical context, lack of cartilage:cartilage integration may not be a significant short term factor, however from our understanding of joint disease initiation and progression there may be significant long term repercussions (Balint et al., 2005). As Hunziker has noted, cartilage repair without vertical and lateral integration is destined for failure (Hunziker, 2002) 
The materials used to fabricate scaffolds can be synthetic, including but not limited to; poly(lactic acid), poly(glycolic acid), poly(lactic-co-gylcolic acid) copolymers, poly(ethylene oxide) or poly(propylene oxide) polymers that gelate at body temperatures, ceramic composites and hydrogels containing polyethylene glycol polymer based derivatives (Frenkel and Di Cesare, 2004). Natural substances such as; fibrin, collagen, chondroitin sulphate, alginate, agarose, chitosan and hyaluronic acid have also been used to design and produce scaffolds in a rich variety of configurations including woven and nonwoven meshes, sponges, foams, hydrogels, glues, composite bilayer and trilayer hybrid solutions and more recently electrospun nanofibres (Barnes et al., 2007; Geutjes et al., 2006). Each successive iteration in scaffold design has attempted to optimise biocompatibility, porosity, bioresorption, biomechanical strength, cell retention and integration (generally in the vertical dimension) to maximise repair with the major emphasis on defect filling and hyaline cartilage production. The assumption that natural substances such as fibrin, collagen or hyaluronan provide superior templates for cartilage repair of defects is unfounded: they too can be subject to inflammatory or degradative responses (Haisch et al., 2000; Knudson et al., 2000), although the use of autologous biomaterials such as plasma-derived fibrin can negate this effect (Munirah et al., 2007). Even collagen-based scaffolds produce incongruities in lateral integration in experimental animal studies of osteochondral repair (Wakitani et al., 1994). An example of a biomaterial that shows some promise in cartilage repair is HyalograftC ${ }^{\text {TM }}$, an esterified derivative of hyaluronic acid that resorbs in the absence of an inflammatory response (Tognana et al., 2007). Additionally, due to its intrinsic adhesive properties HyalograftC ${ }^{\text {TM }}$ implants do not require suturing, and in clinical studies grafts appear to have good vertical integration with a re-established tidemark (Marcacci et al., 2005). However, no objective histological or biochemical assessment of lateral integration following HyalograftC use has been performed to date (Gobbi et al., 2006).

Given the ethical problems and general difficulties associated with obtaining biopsy material from recovering patients, non-invasive procedures to monitor integration have been devised that principally utilise magnetic resonance imaging (MRI). MRI was originally used to detect joint tissue abnormalities (Pearce et al., 1991; Peterfy et al., 1994). The use of 3D fat-suppressed gradient echo imaging provides good contrast between articular cartilage and underlying bone allowing detection of the thickness and surface contour of repair tissue (Uhl et al., 2005). Also, the use of a charged contrast agent such as gadolinium allows direct visualisation of glycosaminoglycan content in cartilage (Allen et al., 1999). Both these techniques have been used to study the process of cartilage repair non-invasively over long post-operative periods using ACI (Roberts et al., 2003) and MACI (Trattnig et al., 2005, 2006), where they have been most useful in increasing our understanding of the maturation processes that occur during healing, especially with respect to lateral integration. One study, covering the postoperative repair process over 52 weeks, describes the MRI signal from a cell-seeded HyalograftC ${ }^{\text {TM }}$ graft transitioning from a fluid-like signal, to hypo-intensity, and finally isointensity when compared to the surrounding articular cartilage (Trattnig et al., 2006). The iso-tense signal permeates through to the surrounding intact articular cartilage indicating at least on the macroscopic morphological scale that lateral integration has occurred, whether this translates to integration on a microscopic scale is debatable. Other indirect techniques to analyse cartilage repair at the repair tissue boundary include mechanical indentation or ultrasound reflective measurements to quantitatively assess site-specific compressive dynamic stiffness of cartilage at the interface (Kiviranta et al., 2008).

Many techniques of cartilage repair have incorporated the use of growth factors, either released in a controlled manner as polypeptides attached to scaffolds, or, through recombinant expression, to enhance the chondrogenic differentiation and biochemical and biomechanical maturation of implanted cells (Heyde et al., 2007; Lee and Shin, 2007). Specific growth factors such as TGF $\beta 1$, BMP2, BMP-7, FGF-2 and IGF-1 all have been shown to increase proliferation, cell survival, increase or accelerate extracellular matrix production, induce better defect filling and enhance maturation, i.e. transition from fibrocartilage to hyaline phenotype, of repair tissue (Blunk et al., 2002; Gooch et al., 2002; Nixon et al., 2007; Pei et al., 2002). An indirect consequence of stimulatory properties of growth factors has been the perceived improvement in lateral integration. Gratz et al. (2006) developed a quantitative biomechanical method to assess whether IGF1 could improve the tensile modulus of repair tissue and its integration in vivo (Gratz et al., 2006). Results showed that the tensile modulus of repair tissue averaged $0.65 \mathrm{MPa}$ compared to $5.2 \mathrm{MPa}$ in intact controls. Integration strength averaged 1.2MPa, which equated to almost half the failure strength of intact cartilage $(2.7 \mathrm{MPa})$. These parameters were not affected by supplementation with IGF-I. Other indirect factors that may benefit lateral integration include in vitro hydrodynamic and biomechanical conditioning of grafts prior to their implantation. The clear advantage of latter methodologies is that cell seeding, cartilage growth, matrix deposition can be controlled in bioreactors to produce hyaline cartilage under optimal conditions, although again, whether this approach can enhance integration in vivo is yet to be rigorously tested (Schumann et al., 2006). Obradovic et al. studied cartilage disc/ring composites cultured in bioreactors for up to 8-weeks and reported that tissue remodelling and adhesive strength of the integrating interface was generally higher for immature than for mature tissue (Obradovic et al., 2001). The highest integrative repair was attributed to active tissue remodelling by proliferative cells and required several weeks in culture in order to produce a hyaline-like repair tissue. Several studies have shown that low-intensity pulsed ultrasound (LIPUS) can also improve the formation of engineered cartilage tissue in vitro. To have an effect the ultrasound signal must propagate through collagen-rich tissues that have high acoustic absorption coefficients, therefore to be of any benefit chondrocytes should have already established an extracellular matrix prior to ultrasound treatment. LIPUS is used successfully in the 


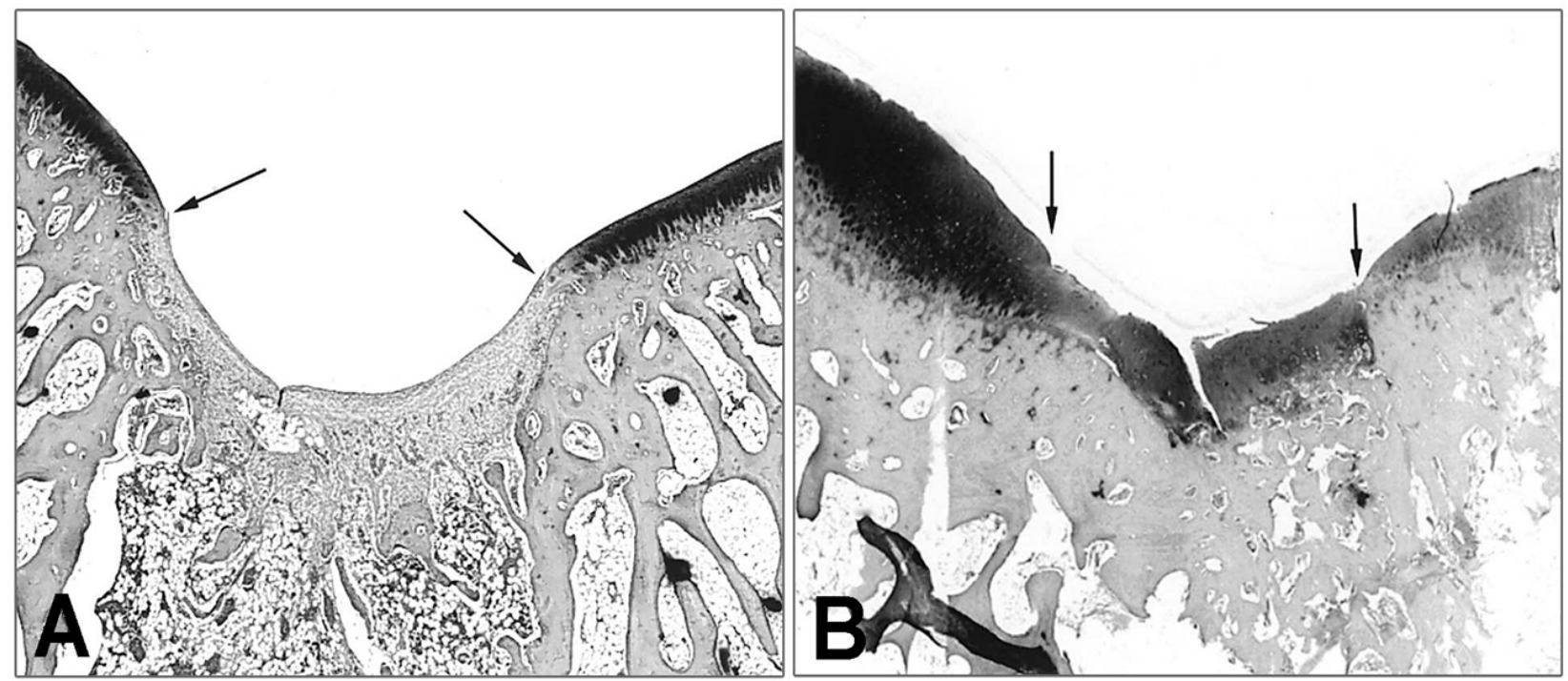

Figure 6. Photomicrographs showing the effects of ultrasound treatment on full-thickness osteochondral defects made in a lapine animal model. (A) An untreated osteochondral defect is shown 4 weeks postoperatively. The repair tissue is composed of undifferentiated tissue that does not stain positively using Safranin-O for proteoglycan. (B) By contrast, the contralateral joint, treated daily with ultrasound, had substantially more subchondral bone repair allied to the presence of repair cartilage that is positive for Safranin-O. (Cooke et al., 2001; used with permission. The original magnification is noted as $\mathrm{x} 5$, but exact dimensions of the image might have changed).

clinical setting as a modified fracture healing system (Gebauer et al., 2005) and has shown some effectiveness in ameliorating the symptoms of osteoarthritis (Srbely, 2008). The use of LIPUS in the repair of osteochondral defects has been examined (Cook et al., 2001; Jia et al., 2005) and data shows that LIPUS administered daily for 40 minutes $\left(30 \mathrm{~mW} / \mathrm{cm}^{2}\right)$ significantly improved cartilage repair in full-depth defects in rabbit knees (Figure 6) (Cook et al., 2001). Over time, less degeneration of the repair tissue was observed in LIPUS-treated knees. The application of LIPUS accelerated the repair process and, perhaps most importantly, resulted in a hyaline-like tissue that appeared to integrate well with the surrounding host cartilage, although integration appears independent of LIPUS because fusion is evident in the control non-LIPUS treated samples also.

\section{Summary}

Articular cartilage is formed from a process of resorption and neo-formation controlled by a surface growth plate (Hayes et al., 2001; Hunziker et al., 2007) populated by progenitor/stems cells (Dowthwaite et al., 2004) that direct slow lateral and rapid vertical growth of articular cartilage during peri-natal growth. Thus, repair of cartilage lesions by cell-seeded matrices, physiological remodelling at a fixed point in space, does not recapitulate normal growth mechanisms either laterally or vertically. Whilst vertical integration with the subchondral bony plate and tidemark reconstitution through intrinsic or extrinsic healing methods is routinely achieved, lateral integration is a chronic problem in cartilage repair. The use of the newest generation of biomaterials allied with increased knowledge and understanding of cartilage biology, especially stem cell biology, can only increase the probabilities of achieving successful and long-term cartilage repair. Clearly, modulation of the biochemical or structural properties of either the native or repair cartilages, for example using collagenase digest, has a direct affect on priming integration, accelerating healing and providing biomechanically stable repair cartilage. Inhibition of chondrocyte cell death or conversely stimulating increased cell density through proliferation and facilitating cellular migration will also have positive effects on cartilage integration. Finally, a deeper understanding of the cellular and molecular characteristics of articular cartilage especially from the perspective of developmental history will also help contribute to overcome apparent impasses in cartilage fusion.

\section{Acknowledgements}

Funding: Department for Business Enterprise \& Regulatory Reform.

\section{References}

Allen RG, Burstein D, Gray ML (1999) Monitoring glycosaminoglycan replenishment in cartilage explants with gadolinium-enhanced magnetic resonance imaging. J Orthop Res 17:430-436.

Amiel D, Coutts RD, Abel M, Stewart W, Harwood F, Akeson WH (1985) Rib perichondrial grafts for the repair of full-thickness articular-cartilage defects. A morphological and biochemical study in rabbits. J Bone Joint Surg Am 67:911-920.

Archer CW, Redman S, Khan I, Bishop J, Richardson K (2006) Enhancing tissue integration in cartilage repair procedures. J Anat 209:481-493. 
Balint L, Park SH, Bellyei A, Luck JV, Jr., Sarmiento A, Lovasz G (2005) Repair of steps and gaps in articular fracture models. Clin Orthop Relat Res Jan(430):208-218.

Barbero A, Grogan S, Schafer D, Heberer M, MainilVarlet P, Martin I (2004) Age related changes in human articular chondrocyte yield, proliferation and postexpansion chondrogenic capacity. Osteoarthritis Cartilage 12:476-484.

Barnes CP, Sell SA, Boland ED, Simpson DG, Bowlin GL (2007) Nanofiber technology: designing the next generation of tissue engineering scaffolds. Adv Drug Deliv Rev 59:1413-1433.

Behrens P, Bitter T, Kurz B, Russlies M (2006) Matrixassociated autologous chondrocyte transplantation/ implantation (MACT/MACI)-5-year follow-up. Knee 13:194-202.

Bentley G, Biant LC, Carrington RW, Akmal M, Goldberg A, Williams AM, Skinner JA, Pringle J (2003) A prospective, randomised comparison of autologous chondrocyte implantation versus mosaicplasty for osteochondral defects in the knee. J Bone Joint Surg Br 85:223-230.

Benya PD, Shaffer JD (1982) Dedifferentiated chondrocytes reexpress the differentiated collagen phenotype when cultured in agarose gels. Cell 30:215224.

Blaney Davidson EN, Scharstuhl A, Vitters EL, van der Kraan PM, van den Berg WB (2005) Reduced transforming growth factor-beta signaling in cartilage of old mice: role in impaired repair capacity. Arthritis Res Ther 7:R1338-1347.

Blunk T, Sieminski AL, Gooch KJ, Courter DL, Hollander AP, Nahir AM, Langer R, Vunjak-Novakovic G, Freed LE (2002) Differential effects of growth factors on tissue-engineered cartilage. Tissue Eng 8:73-84.

Bos PK, DeGroot J, Budde M, Verhaar JA, van Osch GJ (2002) Specific enzymatic treatment of bovine and human articular cartilage: implications for integrative cartilage repair. Arthritis Rheum 46:976-985.

Caplan AI, Bruder SP (2001) Mesenchymal stem cells: building blocks for molecular medicine in the 21 st century. Trends Mol Med 7:259-264.

Cohen I, Melamed E, Robinson D, Nevo Z (2006) Repair of articular cartilage lesions in aged chickens by allogeneic transplantation of fresh embryonic epiphyses. Arch Orthop Trauma Surg 127:763-768.

Cohen I, Robinson D, Melamed E, Nevo Z (2005) Use of a novel joint-simulating culture system to grow organized ex-vivo three-dimensional cartilage-like constructs from embryonic epiphyseal cells. Iowa Orthop J 25:102-107.

Coleman SH, Malizia R, Macgillivray J, Warren RF (2001) Treatment of isolated articular cartilage lesions of the medial femoral condyle. A clinical and MR comparison of autologous chondrocyte implantation vs. microfracture. Ortop Traumatol Rehabil 3:224-226.

Cook SD, Salkeld SL, Popich-Patron LS, Ryaby JP, Jones DG, Barrack RL (2001) Improved cartilage repair after treatment with low-intensity pulsed ultrasound. Clin Orthop Relat Res Oct(391 Suppl):S231-243.
Costouros JG, Kim HT (2007) Preventing chondrocyte programmed cell death caused by iatrogenic injury. Knee 14:107-111.

D'Lima DD, Hashimoto S, Chen PC, Lotz MK, Colwell CW, Jr. (2001) Prevention of chondrocyte apoptosis. J Bone Joint Surg Am 83(Suppl 2):25-26.

Darabi R, Perlingeiro RC (2008) Lineage-specific reprogramming as a strategy for cell therapy. Cell Cycle 7: [no page numbers: Epub ahead of print]

Dell'Accio F, Vanlauwe J, Bellemans J, Neys J, De Bari C, Luyten FP (2003) Expanded phenotypically stable chondrocytes persist in the repair tissue and contribute to cartilage matrix formation and structural integration in a goat model of autologous chondrocyte implantation. J Orthop Res 21:123-131.

DiMicco MA, Sah RL (2001) Integrative cartilage repair: adhesive strength is correlated with collagen deposition. J Orthop Res 19:1105-1112.

DiMicco MA, Waters SN, Akeson WH, Sah RL (2002) Integrative articular cartilage repair: dependence on developmental stage and collagen metabolism. Osteoarthritis Cartilage 10:218-225.

Dowthwaite GP, Bishop JC, Redman SN, Khan IM, Rooney P, Evans DJ, Haughton L, Bayram Z, Boyer S, Thomson B, Wolfe MS, Archer CW (2004) The surface of articular cartilage contains a progenitor cell population. $\mathrm{J}$ Cell Sci 117:889-897.

Dowthwaite GP, Flannery CR, Flannelly J, Lewthwaite JC, Archer CW, Pitsillides AA (2003) A mechanism underlying the movement requirement for synovial joint cavitation. Matrix Biol 22:311-322.

Emans PJ, Hulsbosch M, Wetzels GM, Bulstra SK, Kuijer R (2005) Repair of osteochondral defects in rabbits with ectopically produced cartilage. Tissue Eng 11:17891796.

Englert C, Blunk T, Fierlbeck J, Kaiser J, Stosiek W, Angele P, Hammer J, Straub RH (2006) Steroid hormones strongly support bovine articular cartilage integration in the absence of interleukin-1beta. Arthritis Rheum 54:38903897.

Englert C, Blunk T, Muller R, von Glasser SS, Baumer J, Fierlbeck J, Heid IM, Nerlich M, Hammer J (2007) Bonding of articular cartilage using a combination of biochemical degradation and surface cross-linking. Arthritis Res Ther 9:R47.

Englert C, McGowan KB, Klein TJ, Giurea A, Schumacher BL, Sah RL (2005) Inhibition of integrative cartilage repair by proteoglycan 4 in synovial fluid. Arthritis Rheum 52:1091-1099.

Frenkel SR, Di Cesare PE (2004) Scaffolds for articular cartilage repair. Ann Biomed Eng 32:26-34.

Garciadiego-Cazares D, Rosales C, Katoh M, ChimalMonroy J (2004) Coordination of chondrocyte differentiation and joint formation by alpha5beta1 integrin in the developing appendicular skeleton. Development 131:4735-4742.

Gebauer D, Mayr E, Orthner E, Ryaby JP (2005) Lowintensity pulsed ultrasound: effects on nonunions. Ultrasound Med Biol 31:1391-1402.

Geutjes PJ, Daamen WF, Buma P, Feitz WF, Faraj KA, van Kuppevelt TH (2006) From molecules to matrix: 
construction and evaluation of molecularly defined bioscaffolds. Adv Exp Med Biol 585:279-295.

Giurea A, DiMicco MA, Akeson WH, Sah RL (2002) Development-associated differences in integrative cartilage repair: roles of biosynthesis and matrix. J Orthop Res 20:1274-1281.

Gobbi A, Kon E, Berruto M, Francisco R, Filardo G, Marcacci M (2006) Patellofemoral full-thickness chondral defects treated with Hyalograft-C: a clinical, arthroscopic, and histologic review. Am J Sports Med 34:1763-1773.

Gooch KJ, Blunk T, Courter DL, Sieminski AL, Vunjak-Novakovic G, Freed LE (2002) Bone morphogenetic proteins-2, -12 , and -13 modulate in vitro development of engineered cartilage. Tissue Eng 8:591601 .

Grande DA, Pitman MI, Peterson L, Menche D, Klein M (1989) The repair of experimentally produced defects in rabbit articular cartilage by autologous chondrocyte transplantation. J Orthop Res 7:208-218.

Gratz KR, Wong VW, Chen AC, Fortier LA, Nixon AJ, Sah RL (2006) Biomechanical assessment of tissue retrieved after in vivo cartilage defect repair: tensile modulus of repair tissue and integration with host cartilage. J Biomech 39:138-146.

Haisch A, Loch A, David J, Pruss A, Hansen R, Sittinger M (2000) Preparation of a pure autologous biodegradable fibrin matrix for tissue engineering. Med Biol Eng Comput 38:686-689.

Hayes AJ, MacPherson S, Morrison H, Dowthwaite G, Archer CW (2001) The development of articular cartilage: evidence for an appositional growth mechanism. Anat Embryol 203:469-479.

Heyde M, Partridge KA, Oreffo RO, Howdle SM, Shakesheff KM, Garnett MC (2007) Gene therapy used for tissue engineering applications. J Pharm Pharmacol 59:329-350.

Hjelle K, Solheim E, Strand T, Muri R, Brittberg M (2002) Articular cartilage defects in 1,000 knee arthroscopies. Arthroscopy 18:730-734.

Horas U, Pelinkovic D, Herr G, Aigner T, Schnettler R (2003) Autologous chondrocyte implantation and osteochondral cylinder transplantation in cartilage repair of the knee joint. A prospective, comparative trial. J Bone Joint Surg Am 85-A:185-192.

Huntley JS, Bush PG, McBirnie JM, Simpson AH, Hall AC (2005) Chondrocyte death associated with human femoral osteochondral harvest as performed for mosaicplasty. J Bone Joint Surg Am 87:351-360.

Hunziker EB (2002) Articular cartilage repair: basic science and clinical progress. A review of the current status and prospects. Osteoarthritis Cartilage 10:432-463.

Hunziker EB, Kapfinger E (1998) Removal of proteoglycans from the surface of defects in articular cartilage transiently enhances coverage by repair cells. J Bone Joint Surg Br 80:144-150.

Hunziker EB, Kapfinger E, Geiss J (2007) The structural architecture of adult mammalian articular cartilage evolves by a synchronized process of tissue resorption and neoformation during postnatal development. Osteoarthritis Cartilage 15:403-413.
Hunziker EB, Quinn TM (2003) Surgical removal of articular cartilage leads to loss of chondrocytes from cartilage bordering the wound edge J Bone Joint Surg Am 85-A Suppl 2:85-92.

Isogai N, Kusuhara H, Ikada Y, Ohtani H, Jacquet R, Hillyer J, Lowder E, Landis WJ (2006) Comparison of different chondrocytes for use in tissue engineering of cartilage model structures. Tissue Eng 12:691-703.

Jackson DW, Lalor PA, Aberman HM, Simon TM (2001) Spontaneous repair of full-thickness defects of articular cartilage in a goat model. A preliminary study. $\mathrm{J}$ Bone Joint Surg Am 83-A:53-64.

Jia XL, Chen WZ, Zhou K, Wang ZB (2005) Effects of low-intensity pulsed ultrasound in repairing injured articular cartilage. Chin J Traumatol 8:175-178.

Johnson TS, Xu JW, Zaporojan VV, Mesa JM, Weinand C, Randolph MA, Bonassar LJ, Winograd JM, Yaremchuk MJ (2004) Integrative repair of cartilage with articular and nonarticular chondrocytes. Tissue Eng 10:1308-1315.

Jurgensen K, Aeschlimann D, Cavin V, Genge M, Hunziker EB (1997) A new biological glue for cartilagecartilage interfaces: tissue transglutaminase. J Bone Joint Surg Am 79:185-193.

Kafienah W, Mistry S, Dickinson SC, Sims TJ, Learmonth I, Hollander AP (2007) Three-dimensional cartilage tissue engineering using adult stem cells from osteoarthritis patients. Arthritis Rheum 56:177-187.

Kiviranta P, Lammentausta E, Toyras J, Kiviranta I, Jurvelin JS (2008) Indentation diagnostics of cartilage degeneration. Osteoarthritis Cartilage 16:796-804.

Kleemann RU, Krocker D, Cedraro A, Tuischer J, Duda GN (2005) Altered cartilage mechanics and histology in knee osteoarthritis: relation to clinical assessment (ICRS Grade). Osteoarthritis Cartilage 13:958-963.

Knudson W, Casey B, Nishida Y, Eger W, Kuettner KE, Knudson CB (2000) Hyaluronan oligosaccharides perturb cartilage matrix homeostasis and induce chondrocytic chondrolysis. Arthritis Rheum 43:1165-1174.

Knutsen G, Engebretsen L, Ludvigsen TC, Drogset JO, Grontvedt T, Solheim E, Strand T, Roberts S, Isaksen V, Johansen O (2004) Autologous chondrocyte implantation compared with microfracture in the knee. A randomized trial. J Bone Joint Surg Am 86-A:455-464.

Kuettner KE, Cole AA (2005) Cartilage degeneration in different human joints. Osteoarthritis Cartilage 13:93103.

Kuo CK, Li WJ, Mauck RL, Tuan RS (2006) Cartilage tissue engineering: its potential and uses. Curr Opin Rheumatol 18:64-73.

Lee DA, Bentley G, Archer CW (1994) Proteoglycan depletion alone is not sufficient to stimulate proteoglycan synthesis in cultured bovine cartilage explants. Osteoarthritis Cartilage 2:175-185.

Lee DA, Bentley G, Archer CW (1993) The control of cell division in articular chondrocytes. Osteoarthritis Cartilage 1:137-146.

Lee MC, Sung KL, Kurtis MS, Akeson WH, Sah RL (2000) Adhesive force of chondrocytes to cartilage. Effects of chondroitinase ABC. Clin Orthop Relat Res Jan(370):286-294. 
Lee SH, Shin H (2007) Matrices and scaffolds for delivery of bioactive molecules in bone and cartilage tissue engineering. Adv Drug Deliv Rev 59:339-359.

Liao CJ, Lin YJ, Chiang H, Chiang SF, Wang YH, Jiang CC (2007) Injecting partially digested cartilage fragments into a biphasic scaffold to generate osteochondral composites in a nude mice model. Journal Biomed Mater Res 81:567-577.

Linskens MH, Feng J, Andrews WH, Enlow BE, Saati SM, Tonkin LA, Funk WD, Villeponteau B (1995) Cataloging altered gene expression in young and senescent cells using enhanced differential display. Nucleic Acids Res 23:3244-3251.

Marcacci M, Berruto M, Brocchetta D, Delcogliano A, Ghinelli D, Gobbi A, Kon E, Pederzini L, Rosa D, Sacchetti GL, Stefani G, Zanasi S (2005) Articular cartilage engineering with Hyalograft C: 3-year clinical results. Clin Orthop Relat Res Jun(435):96-105.

Martin I, Miot S, Barbero A, Jakob M, Wendt D (2007) Osteochondral tissue engineering. J Biomech 40:750-765.

Martin JA, Buckwalter JA (2002) Human chondrocyte senescence and osteoarthritis. Biorheology 39:145-152.

Martin JA, Mitchell CJ, Klingelhutz AJ, Buckwalter JA (2002) Effects of telomerase and viral oncogene expression on the in vitro growth of human chondrocytes. J Gerontol A Biol Sci Med Sci 57:B48-53.

Matsusue Y, Yamamuro T, Hama H (1993) Arthroscopic multiple osteochondral transplantation to the chondral defect in the knee associated with anterior cruciate ligament disruption. Arthroscopy 9:318-321.

McGowan KB, Sah RL (2005) Treatment of cartilage with beta-aminopropionitrile accelerates subsequent collagen maturation and modulates integrative repair. J Orthop Res 23:594-601.

Muir H (1995) The chondrocyte, architect of cartilage. Biomechanics, structure, function and molecular biology of cartilage matrix macromolecules. BioEssays 17:10391048.

Munirah S, Samsudin OC, Chen HC, Salmah SH, Aminuddin BS, Ruszymah BH (2007) Articular cartilage restoration in load-bearing osteochondral defects by implantation of autologous chondrocyte-fibrin constructs: an experimental study in sheep. J Bone Joint Surg Br 89:1099-1109.

Namba RS, Meuli M, Sullivan KM, Le AX, Adzick NS (1998) Spontaneous repair of superficial defects in articular cartilage in a fetal lamb model. . J Bone Joint Surg Br 80:4-10.

Nixon AJ, Goodrich LR, Scimeca MS, Witte TH, Schnabel LV, Watts AE, Robbins PD (2007) Gene therapy in musculoskeletal repair. Ann N Y Acad Sci 1117:310327.

O’Driscoll SW, Salter RB (1986) The repair of major osteochondral defects in joint surfaces by neochondrogenesis with autogenous osteoperiosteal grafts stimulated by continuous passive motion. An experimental investigation in the rabbit. . Clin Orthop Relat Res Jul(208):131-140.

Obradovic B, Martin I, Padera RF, Treppo S, Freed LE, Vunjak-Novakovic G (2001b) Integration of engineered cartilage. J Orthop Res 19:1089-1097.
Parsch D, Brummendorf TH, Richter W, Fellenberg J (2002) Replicative aging of human articular chondrocytes during ex vivo expansion. Arthritis Rheum 46:2911-2916.

Pearce RH, Thompson JP, Bebault GM, Flak B (1991) Magnetic resonance imaging reflects the chemical changes of aging degeneration in the human intervertebral disk. $\mathrm{J}$ Rheumatol 27(Suppl):42-43.

Pei M, Seidel J, Vunjak-Novakovic G, Freed LE (2002) Growth factors for sequential cellular de- and redifferentiation in tissue engineering. Biochem Biophys Res Commun 294:149-154.

Peretti GM, Campo-Ruiz V, Gonzalez S, Randolph MA, Wei Xu J, Morse KR, Roses RE, Yaremchuk MJ (2006) Tissue engineered cartilage integration to live and devitalized cartilage: a study by reflectance mode confocal microscopy and standard histology. Connect Tissue Res 47:190-199.

Peretti GM, Randolph MA, Caruso EM, Rossetti F, Zaleske DJ (1998) Bonding of cartilage matrices with cultured chondrocytes: an experimental model. J Orthop Res 16:89-95.

Perka C, Schultz O, Lindenhayn K, Spitzer RS, Muschik M, Sittinger M, Burmester GR (2000) Joint cartilage repair with transplantation of embryonic chondrocytes embedded in collagen-fibrin matrices. Clin Exp Rheumatol 18:13-22.

Peterfy CG, Majumdar S, Lang P, van Dijke CF, Sack K, Genant HK (1994) MR imaging of the arthritic knee: improved discrimination of cartilage, synovium, and effusion with pulsed saturation transfer and fat-suppressed T1-weighted sequences. Radiology 191:413-419.

Qiu W, Murray MM, Shortkroff S, Lee CR, Martin SD, Spector M (2000) Outgrowth of chondrocytes from human articular cartilage explants and expression of alphasmooth muscle actin. Wound Repair Regen 8:383-391.

Ravn P, Warming L, Christgau S, Christiansen C (2004) The effect on cartilage of different forms of application of postmenopausal estrogen therapy: comparison of oral and transdermal therapy. Bone 35:1216-1221.

Redman SN, Dowthwaite GP, Thomson BM, Archer CW (2004) The cellular responses of articular cartilage to sharp and blunt trauma. Osteoarthritis Cartilage 12:106116.

Redman SN, Oldfield SF, Archer CW (2005) Current strategies for articular cartilage repair. Eur Cell Mater 9:2332.

Roberts S, McCall IW, Darby AJ, Menage J, Evans H, Harrison PE, Richardson JB (2003) Autologous chondrocyte implantation for cartilage repair: monitoring its success by magnetic resonance imaging and histology. Arthritis Res Ther 5:R60-73.

Russlies M, Behrens P, Wunsch L, Gille J, Ehlers EM (2002) A cell-seeded biocomposite for cartilage repair. Ann Anat 184:317-323.

Schaefer DB, Wendt D, Moretti M, Jakob M, Jay GD, Heberer M, Martin I (2004) Lubricin reduces cartilagecartilage integration. Biorheology 41:503-508.

Schulze-Tanzil G, de Souza P, Villegas Castrejon H, John T, Merker HJ, Scheid A, Shakibaei M (2002) Redifferentiation of dedifferentiated human chondrocytes in high-density cultures. Cell Tissue Res 308:371-379. 
Schumann D, Kujat R, Nerlich M, Angele P (2006) Mechanobiological conditioning of stem cells for cartilage tissue engineering. Biomed Mater Eng 16:S37-52.

Shapiro F, Koide S, Glimcher MJ (1993) Cell origin and differentiation in the repair of full-thickness defects of articular cartilage. J Bone Joint Surg Am 75:532-553.

Silverman RP, Bonassar LJ, Passaretti D, Randolph MA, Yaremchuk MJ (2000) Adhesion of tissue-engineered cartilage to native cartilage. Plast Reconstr Surg 105:13931398.

Singh NK, Singh GR, Amarpal, Kinjavdekar P, Sharma AK, Mohanty TR, Kumar S, Chae HS, Yoo YM, Ahn CN (2007) Articular cartilage repair with autografting under the influence of insulin-like growth factor-1 in rabbits. J Vet Med A Physiol Pathol Clin Med 54:210-218.

Srbely JZ (2008) Ultrasound in the management of osteoarthritis: part I: a review of the current literature. Journal of the Canadian Chiropractic Association 52:3037.

Steadman JR, Rodkey WG, Rodrigo JJ (2001) Microfracture: surgical technique and rehabilitation to treat chondral defects. Clin Orthop Relat Res Oct (391):S362369.

Szeparowicz P, Popko J, Sawicki B, Wolczynski S (2006) Is the repair of articular cartilage lesion by costal chondrocyte transplantation donor age-dependent? An experimental study in rabbits. Folia Histochem Cytobiol 44:201-206.

Tatebe M, Nakamura R, Kagami H, Okada K, Ueda M (2005) Differentiation of transplanted mesenchymal stem cells in a large osteochondral defect in rabbit. Cytotherapy 7:520-530.

Tew S, Redman S, Kwan A, Walker E, Khan I, Dowthwaite G, Thomson B, Archer CW (2001) Differences in repair responses between immature and mature cartilage. Clin Orthop Relat Res Oct(391):S142-152.

Tew SR, Kwan AP, Hann A, Thomson BM, Archer CW (2000) The reactions of articular cartilage to experimental wounding: role of apoptosis. Arthritis Rheum 43:215-225.

Tognana E, Borrione A, De Luca C, Pavesio A (2007) Hyalograft $C$ : hyaluronan-based scaffolds in tissueengineered cartilage. Cells Tissues Organs 186:97-103.

Tognana E, Chen F, Padera RF, Leddy HA, Christensen SE, Guilak F, Vunjak-Novakovic G, Freed LE (2005) Adjacent tissues (cartilage, bone) affect the functional integration of engineered calf cartilage in vitro. Osteoarthritis Cartilage 13:129-138.

Trattnig S, Ba-Ssalamah A, Pinker K, Plank C, Vecsei V, Marlovits S (2005) Matrix-based autologous chondrocyte implantation for cartilage repair: noninvasive monitoring by high-resolution magnetic resonance imaging. Magn Reson Imaging 23:779-787.

Trattnig S, Pinker K, Krestan C, Plank C, Millington S, Marlovits S (2006) Matrix-based autologous chondrocyte implantation for cartilage repair with HyalograftC: two-year follow-up by magnetic resonance imaging. Eur J Radiol 57:9-15.

Uhl M, Lahm A, Bley TA, Haberstroh J, Mrosek E, Ghanem N, Erggelet C (2005) Experimental autologous osteochondral plug transfer in the treatment of focal chondral defects: magnetic resonance imaging signs of technical success in sheep. Acta Radiol 46:875-880.

van de Breevaart Bravenboer J, In der Maur CD, Bos PK, Feenstra L, Verhaar JA, Weinans H, van Osch GJ (2004) Improved cartilage integration and interfacial strength after enzymatic treatment in a cartilage transplantation model. Arthritis Res Ther 6:R469-476.

Wakitani S, Goto T, Pineda SJ, Young RG, Mansour JM, Caplan AI, Goldberg VM (1994) Mesenchymal cellbased repair of large, full-thickness defects of articular cartilage. J Bone Joint Surg Am 76:579-592.

Walker EA, Verner A, Flannery CR, Archer CW (2000) Cellular responses of embryonic hyaline cartilage to experimental wounding in vitro. Journal Orthop Res 18:2534.

Wang DA, Varghese S, Sharma B, Strehin I, Fermanian S, Gorham J, Fairbrother DH, Cascio B, Elisseeff JH (2007) Multifunctional chondroitin sulphate for cartilage tissue-biomaterial integration. Nat Mater 6:385-392.

Wilke MM, Nydam DV, Nixon AJ (2007) Enhanced early chondrogenesis in articular defects following arthroscopic mesenchymal stem cell implantation in an equine model. J Orthop Res 25:913-925.

Yan H, Yu C (2007) Repair of full-thickness cartilage defects with cells of different origin in a rabbit model. Arthroscopy 23:178-187.

Zarnett R, Delaney JP, Driscoll SW, Salter RB (1987) Cellular origin and evolution of neochondrogenesis in major full-thickness defects of a joint surface treated by free autogenous periosteal grafts and subjected to continuous passive motion in rabbits. Clin Orthop Relat Res Sep(222):267-274.

Zhang Z, McCaffery JM, Spencer RG, Francomano CA (2005) Growth and integration of neocartilage with native cartilage in vitro. J Orthop Res 23:433-439.

Zwilling E (1968) Morphogenetic phases in development. Dev Biol 2:S184-S207. 